American Wildlife Policy and Environmental Ideology: Poisoning Coyotes, 1939-1972

Author(s): Thomas R. Dunlap

Source: Pacific Historical Review, Vol. 55, No. 3 (Aug., 1986), pp. 345-369

Published by: University of California Press

Stable URL: http://www.jstor.org/stable/3639703

Accessed: 18/02/2014 15:49

Your use of the JSTOR archive indicates your acceptance of the Terms \& Conditions of Use, available at http://www.jstor.org/page/info/about/policies/terms.jsp

JSTOR is a not-for-profit service that helps scholars, researchers, and students discover, use, and build upon a wide range of content in a trusted digital archive. We use information technology and tools to increase productivity and facilitate new forms of scholarship. For more information about JSTOR, please contact support@ jstor.org. 


\section{American Wildlife Policy and Environmental Ideology: Poisoning Coyotes, 1939-1972}

\section{THOMAS R. DUNLAP}

The author is a member of the history department in Virginia

Polytechnic Institute and State University.

In February 1972, as part of his environmental state of the union address, President Richard Nixon announced a ban on federal use of poison to kill predatory animals and promised to replace the old aim of killing off worthless "varmints" with a new one, saving both coyotes and sheep by reducing contact between them. His order, and the legislative and administrative action which ratified and extended it, was a major change in policy. Americans had long regarded predators as they had the forests and the Indianssomething to be cleared from the land to make way for civilization-and they had commonly used poison to get

I thank Renee Jaussaud of the National Archives and Records Service and the staff of the National Wildlife Federation for their assistance; David Wake of the Museum of Vertebrate Zoology for permission to use the museum's records; and Starker Leopold, Jack Berryman, and John Gottschalk for interviews. I received useful criticism on an earlier draft of this article from colleagues in my history department, and I wish to acknowledge research grants from the history department and the College of Arts and Sciences of Virginia Polytechnic Institute and State University. 
rid of "vermin." Federal predator control work, begun in 1915, enjoyed strong support from the ranchers it served and was, at that time, killing between 60,000 and 100,000 coyotes a year. ${ }^{1}$ Now, with a stroke of the presidential pen, the ground shifted under this well-established and seemingly well-accepted program.

Nixon's announcement can be seen in political termsthe action of a President seeking reelection and anxious to win environmental votes. This perspective, though correct, neglects more important, long-range influences. The ban, however much it owed to immediate circumstances, was the result of a long evolution of public ideas under the influence of science and of efforts by conservation and humane organizations opposed to poisoning. Even in the short-term, politics was not all; changes in law and the bureaucracy played an important part in the decision. At the center of the fight was the coyote poison-Compound 1080-which was the mainstay of predator control after World War II. ${ }^{2}$ It came on the scene before the environmental era, and its initial use and regulation reflected the sentiments of an earlier period. As environmental ideas became more popular it became a symbol-for the woolgrowers part of a modern technology which sustained mankind in the face of an implacably hostile nature, for the environmentalists an example of reck-

1. Richard Nixon, "Special Message to the Congress Outlining the 1972 Environmental Program," in Public Papers of the Presidents of the United States: Richard Nixon, 1972 (Washington, D.C., 1974), 173-189; Executive Order 11643, Feb. 8, 1972, Federal Register, XXXVII, 2875. The EPA order cancelling and suspending registration is in Federal Register, XXXVII, March 18, 1972, p. 5718. See also Michael J. Bean, The Evolution of National Wildlife Law (2nd ed., New York, 1983), 235-240; T. S. Palmer, "Extermination of Noxious Animals by Bounties," in U.S. Dept. of Agriculture, Yearbook of Agriculture, 1896 (Washington, D.C., 1897), 55-68; Stanley P. Young and Edward A. Goldman, The Wolves of North America (1944; 2 vols., New York, 1964), I, 296-335; U.S. Congress, House of Representatives, Committee on Merchant Marine and Fisheries, Subcommittee on Fisheries and Wildlife Conservation, Hearings on Predatory Mammals and Endangered Species, 92 Cong., 2 sess. (1972), 69.

2. Chemically, the compound is sodium fluoroacetate; 1080 was its laboratory number during wartime tests. 
less disregard for the natural world on which humanity depended. ${ }^{3}$ The ban of 1972 came as part of a sweeping change in the philosophy of wildlife policy, a movement from human management for immediate ends to a policy which considered more distant goals and had as a major objective the stability of the biological system.

The career of 1080 shows how changes in scientific knowledge and public ideas about nature were applied to one area of wildlife policy and made what had been an accepted agricultural practice a controversial problem in environmental politics. The social and legal setting into which 1080 was introduced in 1945 dictated the way in which it was judged, accepted, and used, and reflected the concerns of the preenvironmental era. Thereafter, scientific knowledge undermined the assumptions on which the program was based and the rationale for using 1080 . Finally, changes in society, law, and administration allowed opponents of the poisoning program to mobilize a mass constituency and to use their leverage, through the bureaucracy, to change the program and ban the poison. ${ }^{4}$

3. There is a large collection of this literature in file: "Poison 1080, Articles and Publications, 1945-1968," General Files, Division of Wildlife Research, Record Group 22, Records of the U.S. Fish and Wildlife Service, National Archives (hereafter cited as RG 22). See also Jack Olsen's Slaughter the Animals, Poison the Earth (New York, 1971).

4. Thomas R. Dunlap, “'The Coyote Itself': Ecologists and the Value of Predators, 1900-1972," Environmental Review, VII (1983), 54-70, is an overview of ecological ideas about predation and a discussion of the role of science in forming attitudes. The current article and an earlier one in this jour $\rightarrow \rightarrow$ "Values for Varmints," PHR, LIII (1984), 141-161, expand and develop themes touched on in "The Coyote Itself." The earlier essay discusses the protests of mammalogists against predator control in the 1920s, while this article deals with one major policy change in the post-World War II period. All three are parts of a larger work on wildlife policy and ideas about wildlife in industrial America, a subject that few historians have studied. A section in Frank Egerton's "The History of Ecology: Achievements and Opportunities, Part Two," Journal of the History of Biology, XVIII (1985), 118-122, surveys the literature on wildlife management. James A. Tober's Who Owns the Wildlife?: The Political Economy of Conservation in Nineteenth-Century America (Westport; Conn., 1981) and Michael Bean's The Evolution of National Wildlife Law (New York, 1983) survey legal developments. There are summaries of control policies in Stanley 


\section{A Program and Poison}

Congress established a federal predator and rodent control program in 1915 as it had many other small programs-as a service for a set of clients. Many people gained and, apparently, none lost. Federal money relieved western woolgrowers of part of the cost of controlling predators on the range, western congressmen were able to point to the program as something they had produced for their constituents, and the agency which did the work-the U.S. Department of Agriculture's Bureau of Biological Survey-acquired a regular source of appropriations and people to defend it before congressional committees. The funds appropriated were too small to arouse much public interest, and Congress could argue that the money was returned to the public in the form of cheaper beef, mutton, leather, and wool. Because the public did not care that (or how) coyotes were killed, the woolgrowers, who contributed a significant part of the money for predator control, came to set policy for the program. The same indifference allowed the Office of Predator and Rodent Control (the PARC) to become a semi-independent agency, a situation which did not change when the program was transferred in 1939 to the new Fish and Wildlife Service in the Department of the Interior; PARC remained responsible to the woolgrowers and only formally to its bureaucratic superiors. ${ }^{5}$

Paul Young and Edward A. Goldman, The Wolves of North America (Washington, D.C., 1944) and Stanley Paul Young and Hartley H. T. Jackson, The Clever Coyote (Washington, D.C., 1951), 171-222. Sections of Donald Worster's Nature's Economy (San Francisco, 1977), notably chapter 13, discuss predator control, but there is little else in the historical literature.

5. Congress set up the operation as an experiment in 1914 and began regular appropriations in 1915. In 1931 it passed the Animal Damage Control Act, giving the program a legal mandate which lasted until 1972. See Jenks Cameron, The Bureau of Biological Survey (1929; New York, 1974), 45-46. On legal questions, see Bean, Evolution of Wildlife Law, 235-241. On the early history of the program, see Thomas R. Dunlap, "Values for Varmints: Predator Control and Environmental Ideas, 1920-1939," Pacific Historical Review, LIII (1984), 141-161. 
The sheepmen wanted the coyote, the only predator numerous enough to concern them, exterminated-and they wanted it done as cheaply as possible. Profit margins were low, and while cutting coyote populations meant fewer dead sheep and less money paid to herders, ranchers were reluctant to spend any more than necessary. The Biological Survey's appropriations, too, were low, and it sought the cheapest method of control. Poison seemed to offer the most return for the money, and PARC research efforts concentrated on better chemicals and more attractive baits. It had begun with drop baits (small pieces of poisoned fat) and "stations," usually a quarter or half a horse carcass laced with strychnine. In the 1930s it tried dropping the poisoned pieces out of airplanes, and it began using the "coyote getter," a device which fired a charge of sodium cyanide into an animal's mouth.

In 1937 the Biological Survey's Denver Wildlife Research Laboratory began working on ways to protect sheep on lambing grounds high in the mountains. Snow closed the passes until shortly before lambing began and the only practical way to protect the sheep was with bait stations put down in the fall which would kill coyotes all winter. Trials were successful, but the most effective poison, thallium sulfate, promised to cause as many problems as it solved. Its use in California in 1929-1930 had raised a storm of protest against "extermination" and the "slaughter" of "innocent" wildlife, forcing PARC officials to an unusual public defense of the program. ${ }^{6}$ Using thallium in the mountains threatened to bring more

6. Joseph Grinnell, "Wholesale Poisoning of Wild Animal Life," Condor, XXXIII (May 1931), 131-132; Annie M. Alexander, "Control, Not Extermination, of cynomys Ludovicianus Arozonensis," Journal of Mammalogy, XIII (Aug. 1932), 302; Jean M. Linsdale, "Facts Concerning the Use of Thallium in California to Poison RodentsIts Destructiveness to Game Birds, Song Birds and Other Valuable Wildlife," Condor, XXXIII (May 1931), 92-106; T. Gilbert Pearson, "Poisoning Birds and Mammals," Bird-Lore, XXXIII (Sept.-Oct. 1931), 362-364; Calif. Dept. of Agriculture, "The California Ground Squirrel Control Program," Special Publication 109, by Eugene S. Kellogg (Sacramento, 1931). 
complaints, for it was inhumane (killing very slowly and with much pain) and indiscriminate. In 1944 Weldon B. Robinson, in charge of the project, found dead around the stations (presumably poisoned): 673 coyotes, 24 dogs, 3 badgers, 8 ground squirrels, 4 weasels, 1 cat, 4 eagles, 4 hawks, and 9 magpies. The counts were, he admitted, partial and biased toward the coyote column. ${ }^{7}$

Despite these drawbacks the PARC found it hard to reject thallium out of hand. World War II increased the demand for wool and mutton, decreased the availability of ammunition and traps, and made it difficult to find and keep herders, who were drafted or attracted to higher-paying jobs. Thallium had also been spectacularly successful; it cut losses to predators in the test areas by seventy-five to ninety-six percent. Ranchers, Robinson said, were "very insistent in their demands that the use of the poison be continued." The results "have been so convincing . . . that to withdraw. . . [it] would result in serious repercussions in the control program." If the PARC did not begin using thallium on a regular basis, he warned, the sheepmen would, and the dead dogs and wildlife would reflect on the agency, regardless of its involvement. The Service, he concluded, had to use the thallium bait stations, but that use should be carefully monitored. ${ }^{8}$ His concern, it should be noted, was not that use would bring opposition to the policy of poisoning or predator control, but that it would provoke charges of cruelty to animals or destruction of wildlife. Bad publicity would not be fatal to the program, but it would force the PARC to spend time and political capital defending itself. Publicity, though, was unavoidable in one form or another. It looked by 1944 as if thallium could not be safely used (in a political sense) and could not be banished.

7. Weldon B. Robinson, "Merits and Demerits of Thallium in the Control of Coyotes," (1944) 28, in Research Reports, Division of Wildlife Research, RG 22.

8. Ibid., 36-37, 44-46. See also E. R. Kalmbach to Ira N. Gabrielson, Sept. 2, 1944, with Robinson's manuscript, "The Thallium-Studded Station as a Means of Coyote Control in Acute Predation Areas" (1944) in Research Reports, Division of Wildlife Research, RG 22. 


\section{A New Poison}

Ten-eighty allowed the PARC to avoid this unpleasant dilemma. Developed as a rodenticide during World War II, it proved to be extremely toxic to canids as well. In 1945 the Fish and Wildlife Service began testing it on coyotes, and found it quite promising. It was so deadly to coyotes that a small dose would kill them quickly. (A lethal dose for coyotes was a few mouthfuls of a bait treated at the rate of 1.6 grams of 1080 per hundred pounds of meat.) Other species were less susceptible. Hence, using 1080 instead of thallium, it was believed, would result in fewer problems with bait-shyness from sublethal doses (getting sick but not dying, and thereafter avoiding baits), fewer complaints about suffering animals, and less damage to nontarget species. ${ }^{9}$ Enthusiasm ran high, with one PARC agent speculating that 1080 might mean the end of all predators. But it was not an ideal material. The pure compound was deadly to humans, and there was no antidote. It was water-soluble and might contaminate streams and ponds. In addition, it was so stable there was the danger of secondary poisoning, particularly in rodent control operations. If coyotes died from eating poisoned ground squirrels it would not matter, but farm dogs would be just as susceptible. $^{10}$

Pressure from the woolgrowers, the chance to reduce predator populations, and the apparently greater hazards of thallium outweighed the disadvantages of using 1080. Still, the decision came slowly. Debate within the Fish and Wildlife

9. Eric Peacock, "Sodium Monofluoroacetate," (1964), 1-6, typescript in file: "Correspondence 1080," General Records, Division of Wildlife Services, RG 22; Lewis Laney, "New War Born 1080 Coyote Poison May Kill All Predators," New Mexico Stockman (May 1948), 75, copy in file: "1080 Articles and Publications," ibid.

10. Peacock, "Sodium Monofluoroacetate," 7; Memo 121, Oct. 24, 1945, by Dorr D. Green, Chief of the Division of Predator and Rodent Control, in which he said, "Careful handling and the danger of secondary poisoning cannot be overemphasized." Fall: "1080 Articles and Publications," RG 22. See also E. R. Kalmbach to Lloyd W. Swift, May 8, 1947, in file: "Advisory Board on Wildlife Management-Predator Control, 1964," Correspondence of the Museum of Vertebrate Zoology, University of California, Berkeley (hereafter cited as Correspondence, MVZ). 
Service over the potential dangers delayed use until 1947 and produced a stringent set of regulations, each part "carefully reviewed as to its effectiveness in promoting desirable relations between the Service and the public." "The Service got the manufacturer, Monsanto Chemical Corporation, to sign a "gentleman's agreement" which would limit sales to the Fish and Wildlife Service, other government agencies with a legitimate use for the product, and licensed exterminators. The Service decided to use $\mathbf{1 0 8 0}$ for predator control only west of the 100th meridian, the less-settled part of the country, and there only in areas with serious problems where other methods were not working. The chemical would be employed only in winter bait stations, and these stations would be placed at a density of no more than one per congressional township (thirty-six square miles). The regional director had to approve each location-away from roads, improvements, and water. Only agents trained and authorized by the Service to use 1080 would handle the baits. They were to place the poisoned carcasses in approved locations as late in the fall as possible, remove them as soon as they could in the spring, and personally burn all the remains. ${ }^{12}$

The regulations proved more impressive in theory than in practice. The program was not controlled by scientists and bureaucrats in Washington but by the people who provided the political and much of the financial support-the woolgrowers-and they soon forced the Service to employ 1080 much more extensively. In 1949 E. R. Kalmbach complained from Denver that the initial guidelines had been discarded, and the Service was "promoting the use of 1080 far beyond

11. C. C. Presnall to George Kerr, March 11, 1947, file: "Correspondence 1080," General Files, Division of Wildlife Services, RG 22. Presnall pointed out that "[p]ublic relations were a major consideration in drawing up" the regulations on 1080.

12. "Statement of Policy Adopted by Fish and Wildlife Service for Use of Compound 1080 (Sodium Monofluoroacetate) in Poison Stations to Kill Coyotes" (Nov. 5, 1947) in file: "1080-Misc. 1946-1952, ADC," ibid. The set of memos in this file, though incomplete, is useful in tracing the internal debate over the new chemical. 
the limits that have been recommended through adequate research." He was particularly upset about references to tests and experiments, which gave the impression that work done at his laboratory justified the expansion. This, he said, was not the case. "It is not surprising," he stated, "that my viewpoint is quite consistently at variance with that of those engaged in the operational program. In actual practice, their primary responsibilities are to meet the wishes of a single industry." The Service, he declared, was making a mistake. "Whereas it may seem logical to heed the opinions of those interests from which much of our finances emanate, it is my conviction that we have gone too far in that direction. Already the unorganized opposition is being heard, and I feel that in time this will take more coherent shape." ${ }^{13}$ He complained again, two years later, that the Service was using too much 1080 . The stations $(15,289$ in 1949 and 16,668 in 1950) "covered" about half the West. Some states were almost saturated with stations-91\% of Idaho, $83 \%$ of Utah, and $71 \%$ of Nevada. And this, he pointed out, had taken place without reducing the use of traps, guns, and strychnine, and only four years after the Denver laboratory had recommended, and the Fish and Wildlife Service had approved, the use of 1080 "primarily on acute predation areas where other methods have not gained the desired degree of control." 14

There were other indications that the system was not working. Increased use and familiarity caused carelessness and violations of safety precautions. In 1949, an agent complained: "As for the sheepmen moving our 1080 stations, this happens more or less all over, and I do wish we could do something to stop them from doing it." In another case a field agent accepted a rancher's offer to destroy three stations on his property in the spring (which saved him a trip and

13. E. R. Kalmbach to C. C. Presnall, Feb. 14, 1949 in file: " 1080 CorrespInstructions to Regions (ADC)," ibid.

14. E. R. Kalmbach, memo of Jan. 10, 1951, in file: "Poison 1080-Studies of," ibid. 
some work but was a violation of regulations). Then the rancher failed to do it. Clarence Cottam, head of the Service's Division of Wildlife Research, complained in 1951 that some agents were leaving the stations out all summer. Examples of such flagrant breaches of regulations continued to fill the Service's "violations" file. ${ }^{15}$ Individual infractions and carelessness were not the only problems. In 1953 local officials in Campbell County, Wyoming, purchased two and a half pounds of 1080 for predator control, an amount which PARC agents later estimated would satisfy the legitimate needs of the entire state. A decade later a memo noted that federal use of 1080 in California had been 14.7 ounces while state use (mainly for forest and rangeland rodent control) had been 6,000 ounces. There must, the memo added, be "much irresponsible use here." 16

Cottam, a long-time inside critic of the Service's poison policies, blamed the organization's top level. These men, many of whom had served in the PARC for years, were, he thought, willing to bend or break regulations for the sake of the ranchers and the field men. The problem, though, went beyond Washington headquarters. It was structural. The program was so closely tied to the woolgrowers that it was almost impossible to shape a policy which was not based on "the opinions of those interests from which much of our finances emanate." Those "interests" provided political support for the program, much of the money, and permission for the PARC to work on their land. The people in the field were usually from the local population and shared its values. Even when they were originally from other areas, they had to live with the woolgrowers. The Washington office could say what it liked; the final word on policy belonged to the woolgrowers. $^{17}$

15. File: "Poison-1080-Violations," ibid.

16. John Gottschalk to Stanley Cain, Oct. 19, 1965, file: "Poison 1080, 19651966," ibid.

17. Cottam continued to be suspicious; see his letters in file: "Advisory Board on Wildlife Management, 1963, Correspondence, MVZ." 
And they wanted poison. Low prices, rising costs, and vigorous foreign competition forced them either to reduce their operations or run their flocks unattended on the open range. Unwilling to cut their herds, they cut their herderswith the aid of 1080 . In the late 1950s a PARC staff member told of talking to a rancher who had raised " 7,000 lambs that spring without a single known loss to predators! And this was accomplished in lambing on the open range, no herders, no fences!" When asked what would have happened if he had tried that twenty years ago, the man "just grinned and shook his head." Pressed, he said that if he "had been fool enough to try lambing without herders and dogs in that area in 1946when the 1080 program began-the coyotes would have eaten him out of house and home." 18

\section{Changing Knowledge, Changing Values}

The poisoning program expanded rapidly because the ranchers wanted it, but also because the opposition, such as it was, did not challenge the program in a fundamental way. Mammalogists complained about the possible toll of nontarget species, humane societies about pain and suffering, and some sportsmen, particularly in the late 1940s, about the deadliness of 1080 and the possibility that it would kill game animals. The PARC dealt with these critics by pointing to the chemical's selective, quick action and the precautions it took to minimize the exposure of innocent animals. Mountain lion hunters, losing dogs to the large bait stations in the high country, remained unconvinced, but they posed no threat to the program. ${ }^{19}$ In the early $1950 \mathrm{~s}, 1080$ seemed to be a superthallium-extremely effective (coyote casualties were on the rise), humane, and safe for nontarget species.

18. Charles L. Cadieux to Howard J. Matley, Jan. 16, 1961, file: "Poison 1080, 1960-1963," General Files, Division of Wildlife Services, RG 22.

19. File: "Poison, Use of Poisons, Criticism of, 1949-1965;" and file: "Poison 1080, Criticism of, Use of, 1947-64," ibid. 
The apparent acceptance of predator poisoning masked new developments: changes in scientific understanding of predation and a shift in public opinion. Opposition to the program of killing coyotes had been based upon romantic, sentimental, or aesthetic grounds. As ecological science developed and wildlife research increased, opponents acquired a stronger scientific base. The nature of the opposition also changed. What had been a fringe position in the 1930s - that wild animals should not be made to suffer - was by the $1950 \mathrm{~s}$ and 1960s more acceptable to the public. In addition, advocates were better organized, more sophisticated, and capable of appealing to a mass audience. Humane societies had earlier been either small and aggressive (like the Anti-Steel Trap League in the 1920s) or large and unconcerned with wildlife issues. In the 1960s there appeared new groups, larger than the old radical ones and more aggressive and more interested in wildlife than the mainstream. They acquired paid staffs and published magazines and newsletters, but more importantly, they had scientists on their boards who contributed articles for their publications and helped them argue for humane treatment of wild animals with research results from physiology, ecology, and ethology.

The maturation of animal ecology in the 1930s provided the scientific basis for the new opposition. Scientists, studying animal communities by looking at food chains, trophic levels, niches, and ecosystems, began to see how species interacted and that even apparently useless ones had a function. Research on game populations, guided by these ecological principles, undermined common assumptions about predation and its effects on natural populations. Predation, it seemed, was not a major factor controlling small game, and predator control was not the key to abundance. ${ }^{20}$ Field experience

20. Starker Leopold stressed the importance of repeated studies in convincing biologists of the importance of food and cover and the relative ineffectiveness of predator control as a means of building game populations. Interview with Leopold, June 18, 1981. On the new research, see Paul Errington, "Bobwhite Winter Survival in an Area Heavily Populated with Grey Foxes," Iowa State College Journal of Science, 
forced game managers to reassess their position on controlling predators to increase the supply of large game. People had thought that man would replace the natural predators he had exterminated, but this was not happening. The most spectacular failure of this idea (an example which became a conservation landmark) was the collapse of the deer herd in the Kaibab National Forest on the north rim of the Grand Canyon. Protected from predators for more than twenty years, the area seemed to be a hunter's dream. Then, in the winter of 1924-1925, animals began dying of starvation and disease. The herd continued to decline for a decade, and investigation showed that the deer had destroyed their range. ${ }^{21}$ This problem and similar difficulties in other areas convinced most game managers that preserving the animals' habitatfood supply, breeding areas, shelter from predators and weather-and the restoration of natural ecological balances were the best ways to aid game populations. Game experts were, by the 1950s, not inclined to support predator control to increase game populations or to rely on hunters to keep game populations down to the limits of the area.

Ecological studies changed the arguments of the PARC's opposition by changing its view of nature and of predation.

VIII (1933-1934), 130; Errington, "Vulnerability of Bobwhite Populations to Predation," Ecology, XV (April 1934), 110-127; Errington and Herbert L. Stoddard, "Modifications in Predation Theory Suggested by Ecological Studies of the Bobwhite Quail," Transactions of the Third North American Wildlife Conference (Washington, D.C., 1938), 736-740.

21. Ariz. Dept. of Game and Fish, "The Kaibab Deer Herd: Its History, Problems, and Management," Wildlife Bulletin No. 7, by John P. Russo (Phoenix, 1964); U.S. Dept. of Agriculture, Forest Service, "The Kaibab Deer: A Brief History and Recent Developments” (May 1931), by Walter G. Mann and S. B. Locke, copy courtesy of E. Raymond Hall, Dyche Museum of Natural History, University of Kansas, Lawrence. For an example of the long-term effect of this incident, see James B. Trefethen, "The Terrible Lesson of the Kaibab," National Wildlife, V (June-July 1967), 4-9. Aldo Leopold's famous essay, "Thinking Like a Mountain," in A Sand County Almanac (New York, 1949), 129-133, is based on this experience. Graeme Caughley dissented from the conventional wisdom in "Eruption of Ungulate Populations with Emphasis on Himalyan Thar in New Zealand," Ecology, LI (Winter 1970), 53-72. 
As early as 1935 Bird-Lore, the National Audubon Society's magazine, began citing the findings of ecological research as a guide to wildlife policy; by the late 1930s it had discarded the distinction between "good" and "bad" species. No longer, for instance, did the magazine argue for hawks on the grounds that they were "useful" because they killed mice. All animals, it now said, were valuable as parts of natural biological systems. After World War II the Audubon Society found support in the popular works of scientists and nature writers who decried predator killing as unjustified and destructive to wildlife. Nature writing, which had focused on human reactions to natural scenes or on individual animals, came increasingly to depict what Rachel Carson would call the "web of life." 22

A major contribution of ecological research was the development of a scientific rationale for what had been a romantic notion. Aldo Leopold, a forester turned game manager turned ecologist and nature writer, was the most important person in bringing ecology to support the preservation of all nature as a system. Leopold had begun his career committed to maximum production and human management, and he carried these concepts over into his research on game. ${ }^{23}$ The experiences of the Kaibab, his survey of game conditions in the upper Midwest in 1928-1930, and his con-

22. The Audubon Society's magazine was entitled Bird-Lore until 1940 when it became Audubon. Continuity and coverage make this the single most useful publication on conservationist thought. Durward Allen's Our Wildlife Legacy (New York, 1954) is an example of the new scientific studies of the period. The shift in point of view in popular nature writing is a complex subject. The interested reader might compare John Burrough's essays or Henry Beston's classic, The Outermost House (1928; New York, 1971), with Rachel Carson's Under the Sea Wind (New York, 1941) or Donald Culross Peattie's A Prairie Grove (New York, 1938). A good guide to the older literature is Edwin Way Teale's "The Great Companions of Nature Literature," Audubon, XLVI (Nov.-Dec. 1944), 363-366.

23. The evolution of Leopold's ideas on wildlife management is treated in Susan Flader, Thinking Like a Mountain (Columbia, Mo., 1974). My discussion owes a great deal to Flader; even my work in the Leopold Papers was affected by my coming to that material with her excellent study in mind. 
tinuing involvement with game conditions in the United States (supplemented with trips to Germany and Mexico) changed his ideas. By the late 1930s he had come to believe that the best management was that which restored, as nearly as possible, the full complex of species that had inhabited an area. The first essential for stability, he preached, was diversity. In "The Land Ethic" he proposed a new way to approach nature: as a citizen of an interdependent community with the ethical obligation to preserve that community. He backed this ethical stand with ecological science and developed his ideas in the essays collected as $A$ Sand County Almanac, published in 1949. The book has become an environmentalists' bible.

Widespread acceptance of another idea-that mankind should not cause unnecessary suffering-stimulated the growth of the humane movement, and some parts of it became militantly committed to helping wildlife. By the $1960 \mathrm{~s}$ this faction had gone beyond the old campaign against the steel leg-hold trap and "inhumane" poisons and was opposing all "unnecessary" animal death. Defenders of Wildlife, a descendant of the Anti-Steel Trap League of the 1920s, now challenged the basic program of the PARC-killing coyotesand used scientific evidence to make its case. ${ }^{24}$ Predators were not only an essential part of the ecology, they also had a welldeveloped, complex social life in which they formed emotional attachments to each other. These arguments, but especially the latter, gained wide circulation with the publication in 1963 of Farley Mowat's Never Cry Wolf and even more in

24. The development of humane sentiments is well treated in James C. Turner's Reckoning with the Beast (Baltimore, 1980). On early humane society activity on behalf of wildlife, see the Rosalie Edge Papers, Conservation Center, Denver Public Library; the Vernon Bailey Papers, Smithsonian Institution Archives; and John Richard Gentile, "The Evolution and Geographic Aspects of the Anti-Trapping Movement: A Classic Resource Conflict" (Ph.D. dissertation, Oregon State University, 1983). The positions and tactics of the humane movement in the mid-1970s are revealed in U.S. Congress, House of Representatives, Committee on Merchant Marine and Fisheries, Subcommittee on Fisheries and Wildlife Conservation and the Environment, Hearings on Painful Trapping Devices, 94 Cong., 1 sess. (1976). 
1984 when Walt Disney made it into a movie. ${ }^{25}$ The book incorporated Mowat's observations of the wolves' lives with a description of his own changes in attitude. He had gone to northern Canada to study wolves (for the Canadian government) with, he said, all the common prejudices about predators. As he watched them through the summer he came to appreciate them as friendly, intelligent creatures with a place in the world and a right to live. When he experienced a murderous rage on confronting two wolves in their den (they, he fully realized, posed no threat to him), he concluded that it was he, not they, who was the savage. The wolves lived "in the lost world which once was ours before we chose the alien role; a world which I had glimpsed, and almost entered . . . only to be excluded, at the end, by my own self." ${ }^{26}$

\section{Changing Policy}

The new appreciation of nature as interdependent community and of the rights of animals struck at the foundations of the predator control program. Wildlife management, if one accepted the new views, could not proceed as it had-by eliminating "bad" species and encouraging "good" ones. Nature had to be seen as a whole and the consequences of encouraging one species (even sheep) weighed, not in terms of immediate human needs, but for its effect on the entire ecological system. Killing coyotes, hitherto an unobjectionable, if nasty, practice, now seemed to many people taboo, a violation of decent standards.

25. Farley Mowat, Never Cry Wolf (Boston, 1963). The book, to date, has sold a million copies. See also Barry Holstun Lopez, Of Wolves and Men (New York, 1978) and Roger Caras, The Custer Wolf (Boston, 1966). An earlier, scientific presentation of this side of wolf life is in U.S. Dept. of the Interior, National Park Service, "The Wolves of Mount McKinley," Fauna Series No. 5, by Adolph Murie (Washington, D.C., 1944).

26. Mowat, Never Cry Wolf, 163. 
By the late 1950s the "unorganized opposition," described earlier by Kalmbach, was making its presence felt. Even the usually cooperative Forest Service had begun to balk, and PARC men complained about "duty-struck" rangers who were "backsliding." One district agent believed a few zealots were responsible. The rangers, he said, were "being pushed along very much by a few individuals in the Forest Service whose activities are well known to me." ${ }^{27}$ The PARC was baffled, for it could not meet this with its usual tactics-stress on scientific studies, emphasis on the care it took in placing and using poisons, and an appeal to the quick, "humane" action of 1080 . It could hardly change policy, for the woolgrowers remained committed to poisoning and the older ideals of land management, and successfully blocked any action in Congress. There was not, as yet, a public sufficiently angry to force action. Opponents of poisoning then went to the bureaucracy. Those conservation organizations which provided political support to the Fish and Wildlife Service (and some which did not) appealed to the Secretary of the Interior. In 1963, Secretary Stewart Udall responded by asking his Special Advisory Board on Wildlife Management to review the predator control program. His request might have been a way of avoiding action; one of the most hallowed functions of committees is to bury proposals. A study, though, was the necessary preliminary to any policy change and, as it turned out, not a means of delay but a guide for action.

The board's five members were respected figures in wildlife research. Two had been directly involved in the predator control program. Ira N. Gabrielson had worked in the area for thirty years and been head of the Bureau of Biological Survey (1935-1940) and the Fish and Wildlife Service (1940-1946). Clarence Cottam, former head of the Service's

27. Melvin Smith to C. C. Presnall, Dec. 6, 1957; Everett M. Mercer to Regional Director, Sept. 29, 1959, both in file: "Poison 1080," General Files, Division of Wildlife Services, RG 22. 
Division of Wildlife research, had been a Survey biologist from 1929 to his retirement in 1954. Starker Leopold, the chairman, and Stanley Cain were biologists with extensive wildlife experience. The fifth member, Thomas Kimball, had worked for a decade in state game management and was executive vice-president of the National Wildlife Federation, the nation's largest conservation group.

The board's report, presented in March 1964, argued for change. The PARC had defended its poisoning program on the grounds that it was necessary and scientifically sound; the board found that the program was neither. There was little evidence that poisoning actually protected livestock; what evidence there was suggested poisoning was not uniformly effective and was too costly. Other PARC contentions had even less support. The danger from rabies would "not justify" any but limited programs, and then only when there was an epidemic among animals. The argument that native wildlife needed protection from predators was "supported weakly, if at all," by scientific research. According to the board, the poisoning operations were not based on any demonstrated need to curb predator populations, but "on the subjective judgment of the PARC field men or supervisors in conference with livestock operators and agricultural officials." Some supervisors were "careful and conscientious," but "we have abundant evidence that others willingly support almost any control proposal in which someone is interested enough to contribute matching funds." The program has become "an end in itself and no longer is a balanced component of an overall scheme of wildlife husbandry and management," while the PARC had become a "semi-autonomous bureaucracy whose function in many localities bears scant relationship to real need and less still to scientific management." ${ }^{28}$

28. Special Advisory Board on Wildlife Management, "Predator and Rodent Control in the United States," Transactions of the 29th North American Wildlife and Natural Resources Conference (Washington, D.C., 1964), 6, 15. 
The board called on the PARC to reassess its goals in the light of new public attitudes toward wildlife, use the minimum of control consistent with economic interests, supervise field operations more closely, and resist building the program for its own sake. Most important, it recommended a redistribution of power-the appointment of a permanent advisory board which would represent all interests and keep the Secretary informed about "sensitive problems and divergent interests." ${ }^{29}$ The practice of consulting only the woolgrowers had to end. Policy had to take account of the public's new concern for wildlife and the value it placed on animals.

On the surface, at least, there was change. In 1965 Udall appointed a new director, John Gottschalk, for the Fish and Wildlife Service and a new head, Jack Berryman, for the PARC. He and Gottschalk, Berryman recalled, changed thirty-two of thirty-seven state supervisors and all but two of the regional administrators, instituted a training program for field agents to acquaint them with the new policy and the reasons behind it, and began cracking down on violations of regulations. (One such was the poisoning of two dogs belonging to the Colorado representative of the Defenders of Wildlife. $)^{30}$ The PARC changed its name to Division of Wildlife Services and adopted a new policy statement entitled "Man and Wildlife," which incorporated the recommendations of the Special Advisory Board.

The crux of a matter, though, was what would happen in the field. One of the commonest and oldest complaints (dating to the protests by mammalogists in the 1920s) was that field agents would do as they pleased, regardless of official policy. Reform plans, therefore, met with some scepticism. Starker Leopold thought that the final draft of "Man and Wildlife" was all right but he believed that the real test would be in its administration. Thomas Kimball, writing to Gott-

29. Special Advisory Board, "Predator and Rodent Control," 13.

30. Interviews with Jack Berryman, Dec. 17, 1979, and John Gottschalk, Dec. $20,1979$. 
schalk, was less formal: "Knowing some of your co-workers in the West who will be required to carry out these policy changes, and of their political acumen, [I believe that watching you work] should prove a most interesting spectator sport. I don't envy you your job." ${ }^{31}$

Rising interest in the environment meant that the PARC now had Congress to contend with. In the spring of 1966, Representative John Dingell of Michigan, an ardent hunter and conservationist, held hearings on predator control (before the Subcommittee on Fisheries and Wildlife Conservation of the House Merchant Marine and Fisheries Committee). Woolgrowers and western senators and representatives pleaded for more, not less, federal action. The "greatest crisis facing the sheep industry in Wyoming today," declared Representative Teno Roncalio, "is the lack of adequate control of predators." Representative O. Clark Fisher of Texas spoke of a "serious menace" and of the havoc wrought by the "vicious and relentless Mexican [golden] eagle." Conservationists responded by pointing to what they saw as the senseless destruction of wildlife. E. Raymond Hall, a zoologist opposed to predator poisoning since the 1920s, analyzed the growth of the program and its goals, discussed the value of predators in maintaining the balance of nature, and pointed to successful programs that did not use poison. Alfred Etter, Colorado representative of the Defenders of Wildlife (his were the poisoned dogs) argued, using official maps and figures, that the field agents were consistently violating regulations. $^{32}$

The charges and countercharges were similar to those which had been circulating since the 1920s, but the political climate was different. In the early 1930s when Congress had

31. File: "Policy-Corresp. re Policy, Man and Wildlife," in General Files, Division of Wildlife Services, RG 22.

32. U.S. Congress, House of Representatives, Committee on Merchant Marine and Fisheries, Subcommittee on Fisheries and Wildlife Conservation, Hearings on Predatory Mammals, 89 Cong., 2 sess. (1966), 154-157, 214-239. 
held hearings on increased funding and authority for the PARC, congressmen had shown little sympathy with conservationists' arguments and had approved almost all measures to get rid of the "varmints." The public, too, had not taken much interest in dead coyotes. But in 1966 Chairman Dingell opened the hearings by referring to "well known excesses" over the years and to "indiscriminate trapping, shooting, and poisoning programs." Control, he said, should be directed at the offending animals, not at the entire species, and he hoped that government witnesses would review the "initiatives being taken ... to properly manage all wildlife resources with a view toward this public interest and welfare." At this session even the ranchers did not openly seek what had been the common goal only forty years before-the eradication of predators from all but protected areas. Instead they pleaded for control to save money, and promised moderation in their poisoning efforts. ${ }^{33}$

The hearings, though, did not change policy immediately. Many of Dingell's colleagues did not share his views, and there was still not enough public pressure to override opposition from western congressmen. The Department of the Interior could not act unilaterally (given congressional control of its budget) and while the President could, no President, given the political environment, would. The Special Advisory Board had shown that poisoning could not be justified, but it had not produced a case strong enough to condemn the practice. What opponents got, however, was not better scientific evidence, but a change in the political situation. The popular environmental movement of the late $1960 \mathrm{~s}$ helped upset the balance which held the poisoning program in place. It gave opponents the support of a potent political movement (at a time when environmentalism was becoming a national issue) and it opened new ways for them to make their voices heard. The National Environmental Policy Act,

33. Ibid., 1, 89, 144, 185, 244. 
signed into law in January 1970, allowed opponents to make a direct challenge to the program. Two new agencies, the President's Council on Environmental Quality (CEQ) and the Environmental Protection Agency (EPA), changed the bureaucratic structure. They provided ways around the woolgrowers' congressional roadblock.

Encouraged by these developments, Defenders of Wildlife in March 1971 brought suit against the Fish and Wildlife Service, claiming that Section 102 of the NEPA required the Service to produce an environmental impact statement on the predator control program. ${ }^{34}$ More pressure began building against the program two months later, when hikers discovered dead eagles in a canyon near Casper, Wyoming. Searches by the local Audubon Society turned up more- the total was about two dozen-and there was a public outcry and U.S. Senate hearings in June. The old themes of indiscriminate slaughter and inhumane treatment returned in full force. This time Fish and Wildlife Service officials testified that the agency had stopped using thallium compounds several years before because they caused such pain. The main issue on this occasion, however, was the dead eagles. The discovery suggested an illegal war on wildlife. Worse, state authorities seemed to condone it. A pilot who had flown a plane after testified that he had seen Wyoming game and fish officials pass, without comment, a pile of sixty dead eagles, both bald and golden. There were national headlines. ${ }^{35}$

Even before the furor over the eagles, the President's Council on Environmental Quality and the Department of the Interior had agreed to conduct a joint investigation of the predator control program. In the wake of the publicity over the dead eagles the investigation went rapidly. The new

34. Angus A. MacIntyre, "The Politics of Nonincremental Domestic Change: Major Reform in Federal Pesticide and Predator Control Policy" (Ph.D. dissertation, University of California, Davis, 1980), chap. 6.

35. U.S. Congress, Senate, Committee on Appropriations, Subcommittee on Agriculture, Environmental and Consumer Protection, Hearings on Predator Control and Related Problems, 92 Cong., 1 sess. (1971), 4-8, 11, 40-41, 145-167. 
study, done by a committee headed by biologist Stanley Cain, marked a change in the fight over policy. Hitherto, conservation organizations and humane societies, outside the government, had pushed the issue. Now the bureaucracy itself became involved. Now, too, the woolgrowers felt they were losing control. In 1963 they had forcefully and confidently presented their views to the Special Advisory Board; in July 1971, when Secretary of the Interior Rogers Morton announced the names of the committee members, they protested that the panel was stacked with wildlife biologists known to be hostile to the program. ${ }^{36}$ No one, they said, represented the industry and its interests. Morton promised to consult them before making any policy changes, but that did little to disarm their suspicions.

The woolgrowers' concern proved justified, for the investigating committee repeated its predecessor's call for basic changes in the predator control program. ${ }^{37}$ It condemned cooperative funding and the policy of general reduction of coyote populations in order to protect sheep. The program, it said, should concentrate on removing only the offending animals and should avoid poisons in favor of nonchemical methods that would not harm nontarget wildlife.

The committee's recommendations went from the report to policy-Nixon's announcement in February 1972-by a very restricted route, one made possible by the creation of a new bureaucratic setup. In November the committee sent its draft report to the President's Council on Environmental Quality. Lee Talbot, the CEQ's chief scientific advisor, who had been seeking a review of the program since his appointment in 1970, circulated it under tight security in CEQ and

36. Stanley Cain, the chairman, and Starker Leopold had been on the 1964 committee. The other members (John A. Kadlec, Durward L. Allen, Richard A. Cooley, Maurice G. Hornocker, and Frederick H. Wagner) were also wildlife biologists.

37. Advisory Committee on Predator Control, Predator Control-1971 (Ann Arbor, 1971); Stanley A. Cain, "Predator and Pest Control," in Howard P. Brokaw, ed., Wildlife in America (Washington, D.C., 1978), 379-395. 
the Department of the Interior. He got a "dry run" which allowed him to assess the opposition and to tailor recommendations to meet it. He could do this because the CEQ was in the executive office of the President; recommendations did not have to go through Congress. The organization of the Nixon White House further shielded the report. Suspicious and secretive, Nixon had arranged his lines of communication to minimize input and restrict access. Unless there was a leak, the woolgrowers would not even be aware of the report. They were not. Their first inkling of trouble came with Nixon's dramatic announcement in February banning predator poisons on federal lands and calling for legislation to extend the prohibition. By then it was far too late for the woolgrowers to mobilize their congressional allies. ${ }^{38}$

The ban did not result from new scientific evidence; there was little more available to the government in 1972 than to Leopold's group eight years before. No one had been able to show that the program was worth what it cost, and it did kill nontarget wildlife. On the other hand, there was no conclusive proof that poisoning had seriously affected nontarget species. Nixon's acceptance of the report seems primarily to have reflected political considerations. The "environment," physical and biological, was a sensitive issue in 1972, the more so for Nixon because of his recent approval of the supersonic transport plane (SST) and the Alaska pipeline. Environmental opposition to both had been intense. A ban on predator poisons and the announcement of a new policy might help defuse this opposition. The woolgrowers would grumble, but they were unlikely to vote for a Democrat in the fall.

Since 1972 the woolgrowers have been working to modify the total ban on poisons, and under the Ronald Reagan administration have obtained limited use of $1080 .^{39}$ They have

38. MacIntyre, "Politics of Nonincremental Domestic Change," chap. 6.

39. U.S. Dept. of the Interior, Fish and Wildlife Service, "Final Environmental Impact Statement, U.S. Fish and Wildlife Service's Mammalian Predator Damage 
been unable, however, to restore the old system of widespread use of poisons to reduce predator populations. The change since World War II in the American public's ideas about nature has created a constituency for wildlife and a structure of laws, agencies, and lobbying groups to protect it. The closed world of sheepmen, congressmen, and the PARC is a thing of the past, and with it the "conservation" goals of efficient management for immediate human needs which justified the poisoning of coyotes on a large scale. The ban of 1972 marks the end of an era.

Ecological concerns played a central role in the fight over 1080 , and so did environmental organizations and popular acceptance of "environmental" ideas, but it would be incorrect to see the issue and the battle only in terms of a new movement and a new ideology upsetting an old program. Older organizations committed to "conservation" and efficient management, like the National Wildlife Federation, took a hand. New and aggressive humane societies, like Defenders of Wildlife, played an important part, and their motives were at odds not only with environmental ideas and rhetoric but also with the claims of efficient management. Environmentalists and wildlife advocates looked to the preservation of the ecosystem as the ultimate goal; the humane societies were concerned about the suffering and death of individual animals. All opponents of poisoning drew on the new ecological science and set the terms of debate, but the fight over 1080 was part of larger questions: the place of man in nature, of nature in a modern industrial society and economy, and of the rights of animals against those of people. Ultimately it was a matter of values and their expression in policy.

\footnotetext{
Management for Livestock Protection in the Western United States" (Washington, D.C., 1979), 746-747 (typescript and photocopy) chronicles legal changes in the ban (copy courtesy of National Wildlife Federation). See also U.S. Environmental Protection Agency, FIFRA Docket 502, "In the Matter of Notice of Hearing on the Applications to Use Sodium Fluoroacetate (Compound 1080) to Control Predators," decision by Spencer T. Nissen, Administrative Law Judge, Oct. 22, 1982 (copy courtesy of U.S. Fish and Wildlife Service).
} 